\title{
Comparative study on air quality status in Indian and Chinese cities before and during the COVID-19 lockdown period
}

\author{
Aviral Agarwal $^{1} \cdot$ Aman Kaushik $^{1} \cdot$ Sankalp Kumar $^{1} \cdot$ Rajeev Kumar Mishra ${ }^{1}$ \\ Received: 26 May 2020 / Accepted: 15 July 2020 / Published online: 23 July 2020 \\ (C) Springer Nature B.V. 2020
}

\begin{abstract}
Amidst COVID-19 pandemic, extreme steps have been taken by countries globally. Lockdown enforcement has emerged as one of the mitigating measures to reduce the community spread of the virus. With a reduction in major anthropogenic activities, a visible improvement in air quality has been recorded in urban centres. Hazardous air quality in countries like India and China leads to high mortality rates from cardiovascular diseases. The present article deals with 6 megacities in India and 6 cities in Hubei province, China, where strict lockdown measures were imposed. The real-time concentration of $\mathrm{PM}_{2.5}$ and $\mathrm{NO}_{2}$ were recorded at different monitoring stations in the cities for 3 months, i.e. January, February, and March for China and February, March, and April for India. The concentration data is converted into AQI according to US EPA parameters and the monthly and weekly averages are calculated for all the cities. Cities in China and India after 1 week of lockdown recorded an average drop in $\mathrm{AQI}_{\mathrm{PM} 2.5}$ and $\mathrm{AQI}_{\mathrm{NO} 2}$ of $11.32 \%$ and $48.61 \%$ and $20.21 \%$ and $59.26 \%$, respectively. The results indicate that the drop in $\mathrm{AQI}_{\mathrm{NO} 2}$ was instantaneous as compared with the gradual drop in $\mathrm{AQI}_{\mathrm{PM} 2.5}$. The lockdown in China and India led to a final drop in $\mathrm{AQI}_{\mathrm{PM} 2.5}$ of $45.25 \%$ and $64.65 \%$ and in $\mathrm{AQI}_{\mathrm{NO} 2}$ of $37.42 \%$ and $65.80 \%$, respectively. This study will assist the policymakers in devising a pathway to curb down air pollutant concentration in various urban cities by utilising the benchmark levels of air pollution.
\end{abstract}

Keywords Air quality index $\cdot$ China $\cdot \operatorname{COVID} 19 \cdot$ India $\cdot \mathrm{NO}_{2} \cdot \mathrm{PM}_{2.5}$

\section{Introduction}

In the present time, with the emergence of rapid globalisation and urbanisation, megacities in developing nations are facing severe health issues due to ambient air pollution. According to WHO (World Health Organization), seven million people die each year because of exposure to polluted air (UN Environment Programme 2018). Numerous epidemiological studies in the past two decades have highlighted outdoor air

Rajeev Kumar Mishra

rajeevkumarmishra@dtu.ac.in

Aviral Agarwal

agarwalaviral1999@gmail.com

Aman Kaushik

kakukaushik@gmail.com

Sankalp Kumar

sankalp.vibhu@gmail.com

1 Department of Environmental Engineering, Delhi Technological University, Delhi 110042, India pollution as a cause of various respiratory diseases such as asthma, premature deaths and cardiovascular diseases. These have been identified as primary causes of mortality. In such cases, the population living in the vicinity of major roadways in metropolitan cities suffers the most (Park et al. 2020). In urban areas, $80 \%$ of people live in concentrations exceeding the WHO limits (Błaszczyk et al. 2017). Motor-vehicle emitted compounds in urban areas which include carbon monoxide $(\mathrm{CO})$; nitrogen oxides $\left(\mathrm{NO}_{\mathrm{x}}\right)$; coarse $\left(\mathrm{PM}_{10}\right)$, fine $\left(\mathrm{PM}_{2.5}\right)$, and ultrafine $\left(\mathrm{PM}_{0.1}\right)$ particle mass, black carbon, polycyclic aromatic hydrocarbons and benzene which are found in elevated concentrations as reported by Venkatram and Schulte (2018). Moreover, studies suggest that particulate matter and $\mathrm{NO}_{2}$ levels are higher in cities with greater transportation activity and urban backgrounds (Rodríguez et al. 2016). $\mathrm{PM}_{10}$ and $\mathrm{PM}_{2.5}$ are the two primary particulate matters monitored all over the world. However, $\mathrm{PM}_{2.5}$ possesses a higher health risk as compared with $\mathrm{PM}_{10}$ because of its high retention time and ability to penetrate deep into the lungs and enter the bloodstream (US EPA 2018). The WHO ambient air quality guidelines suggest an annual mean $\mathrm{PM}_{2.5}$ concentration limit of $10 \mu \mathrm{g} / \mathrm{m}^{3}$ and $25 \mu \mathrm{g} / \mathrm{m}^{3}$ for the 24-hourly mean. The $\mathrm{NO}_{2}$ 
limit is $40 \mu \mathrm{g} / \mathrm{m}^{3}$, and $200 \mu \mathrm{g} / \mathrm{m}^{3}$ for the annual and 1-h mean, respectively (World Health Organization 2005).

At the dawn of twenty-first century, developing economies like India and China are undergoing rapid industrialisation and modernisation, which are leading to hazardous levels of air pollution similar to the Industrial Revolution in Europe. It is well-understood that megacities in both countries like Beijing, Shenyang, Taiyuan, New Delhi, Mumbai, and Chennai are the world's most polluted cities (Zhu 2005). The primary sources of air pollution in India have been identified as vehicular emissions, industrial emissions, coal combustion, biomass burning, road dust, and refuse burning (Pant and Harrison 2012). Likewise, the poor air quality in China is a matter of global concern. The air pollution caused by transportation and industries is a serious environmental issue in urban settlements, and $50 \%$ of the PM in the urban air comes from traffic emissions ( $\mathrm{Li}$ et al. 2017). Kumar and Joseph (2006) analysed ambient and kerb site air pollution correlation of $\mathrm{PM}_{10}, \mathrm{PM}_{2.5}$, and $\mathrm{NO}_{2}$ in Mumbai, India. The results indicated a strong correlation between $\mathrm{PM}_{2.5}$ and $\mathrm{NO}_{2}$ at the ambient site due to vehicular emission as a result of high traffic density. A 2016 report estimated that only $3 \%$ of the Chinese population and less than $1 \%$ of the Indian population have exposure to $\mathrm{PM}_{2.5}$ concentrations complying with WHO guidelines (IEA OECD 2016), although, an overall monotonic decrease in air pollutants was recorded in China from 2015 to 2018 (Fan et al. 2020). The existing levels of ambient $\mathrm{PM}_{2.5}$ and $\mathrm{NO}_{2}$ are above the safe limit. A 2017 report on global air pollution stated that China and India contribute to $52 \%$ of global $\mathrm{PM}_{2.5}$-attributable deaths (1.525 million deaths) (Health Effects Institute 2019). In the past decades, both countries have been pro-active towards the efforts reducing air pollution. However, no long-term solution has been identified yet. Numerous academic studies have been conducted in both nations regarding the growing air pollution and its health effects. Kumar and Mishra (2018) conducted an assessment of major air pollutants at 36 transport corridors in Delhi, India, and the results of the study concluded that 31 corridors had "severe" and "very poor" AQI, and high traffic volume in most corridors is characterised by traffic-induced human health risks. It has been found that high levels of ambient $\mathrm{PM}_{2.5}$ and $\mathrm{NO}_{2}$ increase the risk of cardiovascular diseases and lung cancer in humans (Liu et al. 2018; Siddique et al. 2010).

In late December 2019, there was an outbreak of a highly contagious disease caused by the novel coronavirus, SARSCoV-2. The first case emerged from Wuhan City, Hubei Province, China. The disease has been identified as Coronavirus disease (COVID-19). It's an outbreak, recognised as a "Pandemic" by WHO, has been extensively worldwide and exponential with more than 200 countries and territories reporting $3,267,936$ cases and 234,703 deaths (7.18\%) as of April 30, 2020 (WHO 2020). Individuals with underlying health problems, weak immunity, and the elderly are most likely to become extreme cases (Chen et al. 2020a). The critical sources of infection are patients infected with the novel coronavirus and those with asymptomatic infection (Wang et al. 2020a). Studies indicate correlation between the long-term exposure to air pollutant and COVID 19 death rate. Cities with hazardous air quality face a serious threat from the pandemic (Wu et al. 2020b; Conticini et al. 2020). Therefore, in the absence of a vaccine or treatment available for COVID19 , there has been a coordinated global response of imposing "lockdown" measures on citizens. As of now, more than a third of the worldwide population is under restriction. India recorded 34,867 COVID-19 cases (as of 30-04-2020) and a nationwide lockdown was imposed in India on March 25, 2020 for 21 days (MoHFW 2020). The lockdown constrained people from stepping out of their homes. Transport services, road, air, and rail, were suspended along with institutions and industrial establishments except for essential goods and services (Jain and Sharma 2020) and has been extended up to May 3, 2020. In parallel, 82,862 cases (as of 30-04-20) were recorded in China and $82 \%$ of these cases were recorded in Hubei Province (National Health Commission of the People's Republic of China 2020).

In Hubei province, Wuhan was regarded as the epicentre (Zhang et al. 2020) of the virus. On January 23, 2020, Hubei province, China, was kept under community quarantine with the shutdown of public transport, educational institutes, business centres, parks, and other social contacts to slow down the spread of COVID-19 (Wilder-Smith and Freedman 2020).

Further restrictions in Hubei province were lifted on March 23, 2020.With the implementation of lockdown and other federal restrictions in various countries around the globe, a visible reduction in air pollution is found in megacities. This study is aimed at quantifying and analysing the reduction in air pollution due to the lockdown imposed in two overpopulated and highly polluted countries of the world, viz. China and India, to determine the effect of lockdown on the air quality in an urban environment. The results of this study will help in gauging the ability of a full lockdown on reducing air pollution. Further, it will help in devising a response plan for unforeseen episodes of the high level of air pollution in urban environments.

\section{Methodology of the study}

\section{Site selection}

For the present study, 6 cities have been selected, each from India and Hubei Province, China. These locations are selected based on the availability of historical air pollution data, population density, monitoring station network, and the number of positive COVID-19 cases per million people. Selected cites 
with their population, the number of monitoring stations taken into account, COVID-19 cases per million people, their geographical coordinates, and start and end date of lockdown are given in Table 1.

\section{Parameters for analysis}

For the analysis of the effect of the lockdown imposed by the governing authorities on the air quality, $\mathrm{PM}_{2.5}$ and $\mathrm{NO}_{2}$ are selected as parameters of the study. Both of these pollutants have a direct relationship with various anthropogenic activities that were restricted due to the lockdown (US EPA 2018; Ministry for the Environment New Zealand 2020). Hence, analysing these parameters assist in espying the effect of lockdown on the air quality of the selected locations.

\section{Data collection and interpretation}

During the data collection, 24-h average concentration ( $\mu \mathrm{g} /$ $\mathrm{m}^{3}$ ) data is taken for $\mathrm{PM}_{2.5}$, and hourly average concentration data is taken for $\mathrm{NO}_{2}$ (ppb) from respective EPAs of the locations selected. The data is collected in China for 13 weeks starting from January 1, 2020 except for Wuhan for which data was collected for 15 weeks since the lockdown was imposed till April 8, 2020. In India, data is collected for 13 weeks starting from February 1, 2020 to April 30, 2020. For the years 2016-2019, the data for Hubei Province, China has been collected from January 1 to March 31, and similarly, for India, the data has been collected from February 1 to April 30.

Weekly average data of $\mathrm{PM}_{2.5}$ and $\mathrm{NO}_{2}$ for the mentioned months has been calculated for the selected monitoring stations. The average value of the $\mathrm{PM}_{2.5}$ and $\mathrm{NO}_{2}$ concentration in a city is calculated by taking an average of all the monitoring stations selected, located at various distant locations throughout the city. The average value of the concentration of $\mathrm{PM}_{2.5}$ and $\mathrm{NO}_{2}$ is converted to individual AQI (AQI $\mathrm{PM}_{2.5}$ and $\mathrm{AQI}_{\mathrm{NO} 2}$ ) by using the protocol suggested by US EPA for reporting the air quality data using the Air Quality Index (AQI) (Mintz 2012).

To analyse the changes in the $\mathrm{AQI}_{\mathrm{PM} 2.5}$ and $\mathrm{AQI}_{\mathrm{NO} 2}$ levels, for each city, various drop percentages are calculated. The immediate drop percentage is calculated by the difference in average $\mathrm{AQI}_{\mathrm{PM} 2.5}$ and $\mathrm{AQI} \mathrm{NO}_{\mathrm{NO}}$ of the weeks before and after the lockdown was enforced. The final $\mathrm{AQI}_{\mathrm{PM} 2.5}$ and $\mathrm{AQI}_{\mathrm{NO} 2}$ drop percentages are calculated by the difference in average $\mathrm{AQI}_{\mathrm{PM} 2.5}$ and $\mathrm{AQI}_{\mathrm{NO} 2}$ of the week before lockdown and the last week when lockdown restrictions were lifted. Five-year and 1-year AQI $\mathrm{PM}_{2.5}$ drop percentages in the year 2020 are calculated for January, February, and March in China and February, March, and April in India. It has been calculated by the difference in average AQI $\mathrm{PM}_{\mathrm{PM} .5}$ of months of years 2016 and 2019 to the same months of 2020 for 5-year and 1 -year drop percentages, respectively.

\section{Results and discussion}

With the parameters of immediate and final $\mathrm{AQI} \mathrm{PM}_{\mathrm{PM} .5}$ and $\mathrm{AQI}_{\mathrm{NO} 2}$ drop percentages, and 5 year and I year drop percentages of $\mathrm{AQI}_{\mathrm{PM} 2.5}$, analysis for the cities in China and India has been done followed by a comparative assessment between the two countries.

\section{Air quality analysis for the selected cities of China}

Due to a large number of reported cases, Wuhan and its neighbouring cities (Huanggang and Ezhou) implemented a lockdown on January 23, 2020 followed by several cities on

Table 1 General Information of the Selected Cities (Office of the Registrar General and Census Commissioner 2011; National Bureau of Statistics of China 2010; Central Intelligence Agency 2018; MoHFW 2020; National Health Commission of the People's Republic of China 2020)

\begin{tabular}{|c|c|c|c|c|c|}
\hline Country & City & Population (in million) & No. of stations monitored & COVID-19 cases per Million & Geographical coordinates \\
\hline \multirow[t]{6}{*}{ China } & Xiangyang & 5.89 & 5 & 199.22 & $30^{\circ} 48^{\prime} 01^{\prime \prime} \mathrm{N} 110^{\circ} 23^{\prime} 11^{\prime \prime} \mathrm{E}$ \\
\hline & Jingzhou & 0.97 & 3 & 1624.47 & $30^{\circ} 13^{\prime} 35^{\prime \prime} \mathrm{N} 111^{\circ} 47^{\prime} 18^{\prime \prime} \mathrm{E}$ \\
\hline & Huanggang & 6.628 & 2 & 438.55 & $30^{\circ} 24^{\prime} 16^{\prime \prime} \mathrm{N} 114^{\circ} 42^{\prime} 49^{\prime \prime} \mathrm{E}$ \\
\hline & Xiaogan & 5.17 & 3 & 679.26 & $31^{\circ} 03^{\prime} 41^{\prime \prime} \mathrm{N} 113^{\circ} 25^{\prime} 37^{\prime \prime} \mathrm{E}$ \\
\hline & Wuhan & 8.11 & 5 & 6204.90 & $30^{\circ} 42^{\prime} 07^{\prime \prime} \mathrm{N} 113^{\circ} 46^{\prime} 52^{\prime \prime} \mathrm{E}$ \\
\hline & Yichang & 4.37 & 5 & 213.18 & $30^{\circ} 41^{\prime} 49^{\prime \prime} \mathrm{N} 110^{\circ} 48^{\prime} 01^{\prime \prime} \mathrm{E}$ \\
\hline \multirow[t]{6}{*}{ India } & Delhi & 18.62 & 5 & 501.03 & $29^{\circ} 03^{\prime} 55^{\prime \prime} \mathrm{N} 76^{\circ} 06^{\prime} 09^{\prime \prime} \mathrm{E}$ \\
\hline & Lucknow & 3.12 & 5 & 88.30 & $26^{\circ} 52^{\prime} 53^{\prime \prime} \mathrm{N} 80^{\circ} 41^{\prime} 49^{\prime \prime} \mathrm{E}$ \\
\hline & Kolkata & 4.98 & 5 & 240.51 & $23^{\circ} 04^{\prime} 44^{\prime \prime} \mathrm{N} 87^{\circ} 17^{\prime} 22^{\prime \prime} \mathrm{E}$ \\
\hline & Mumbai & 13.80 & 5 & 1279.98 & $19^{\circ} 10^{\prime} 38^{\prime \prime} \mathrm{N} 72^{\circ} 23^{\prime} 50^{\prime \prime} \mathrm{E}$ \\
\hline & Chennai & 5.16 & 5 & 1153.44 & $13^{\circ} 07^{\prime} 10^{\prime \prime} \mathrm{N} 79^{\circ} 44^{\prime} 05^{\prime \prime} \mathrm{E}$ \\
\hline & Jaipur & 6.42 & 4 & 234.51 & $27^{\circ} 03^{\prime} 33^{\prime \prime} \mathrm{N} 75^{\circ} 18^{\prime} 19^{\prime \prime} \mathrm{E}$ \\
\hline
\end{tabular}


January 24, 2020 (Wu et al. 2020a). Wuhan, having the highest number of cases than any other city in China enforced lockdown with strict federal orders restraining anthropogenic activity to minimal level ( $\mathrm{Lu} 2020)$, which entailed the highest immediate $\mathrm{AQI}_{\mathrm{NO} 2}(69.35 \%)$ and $\mathrm{AQI} \mathrm{I}_{\mathrm{PM} 2.5}$ drop (15.95\%) among the selected cities. In contrast, Xiangyang recorded the lowest immediate and final $\mathrm{AQI}_{\mathrm{NO} 2}$ drop of $-3.22 \%$ and $-16.40 \%$, respectively. This trend is observed since Xiangyang is one of the most industrialised cities in central China, and due to the high demand for PPE kits and testing equipment, industries were working at double shifts to meet the demand (Hubei Provincial People's Government 2020).

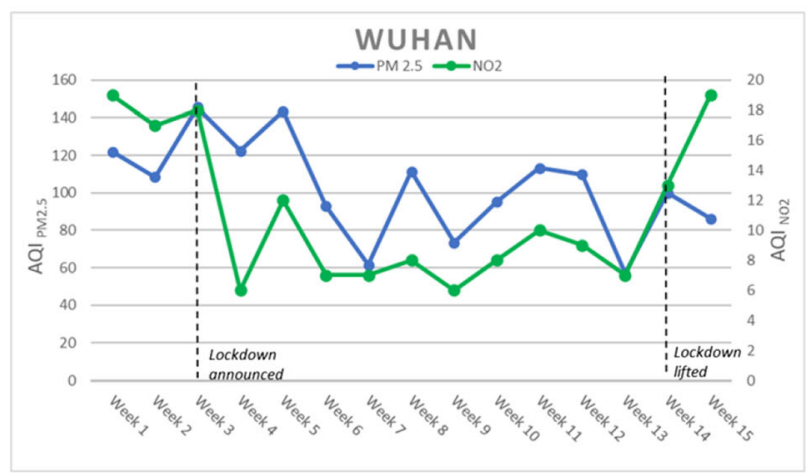

a

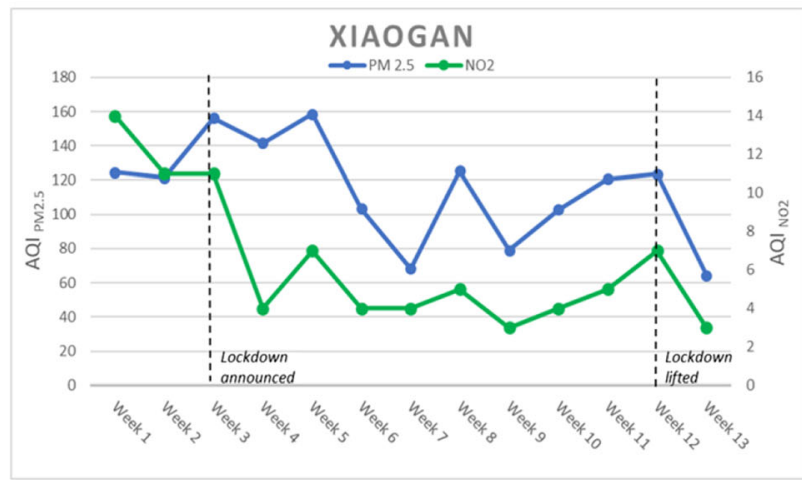

c

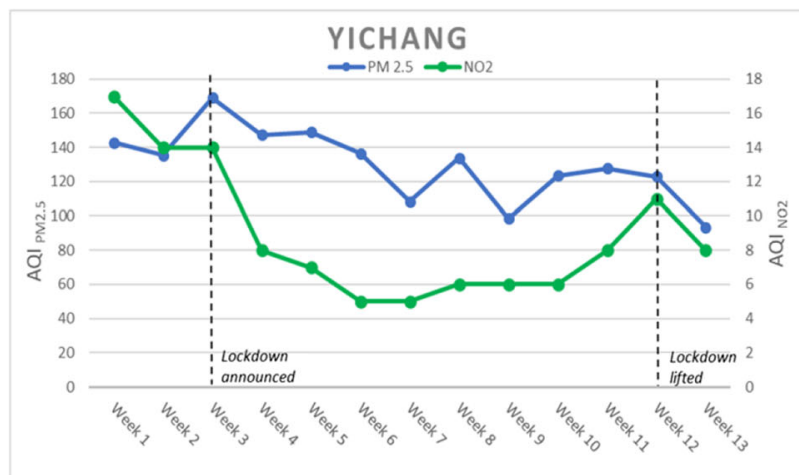

e

Fig. 1 Weekly averages of $\mathrm{AQI}_{\mathrm{PM} 2.5}$ and $\mathrm{AQI}_{\mathrm{NO} 2}$ for cities of China
The average immediate and final $\mathrm{AQI}_{\mathrm{NO} 2}$ drop recorded is $48.61 \%$ and $26.64 \%$, respectively. It can be concluded that the final $\mathrm{AQI}_{\mathrm{NO} 2}$ drop percentage is lower than the immediate $\mathrm{AQI}_{\mathrm{NO} 2}$ drop percentage; as the lockdown progressed, citizens had to get out of their homes for necessary essential commodities. Every city experienced a drop in $\mathrm{AQI}_{\mathrm{PM} 2.5}$ (Fig. 1a, b, c, d, e, and f); on an average, the immediate $\mathrm{AQI}_{\mathrm{PM} 2.5}$ drop is $11.28 \%$; subsequently, the average final AQI $_{\mathrm{PM} 2.5}$ drop is $26.37 \%$. Before lockdown was implemented, every city had $\mathrm{AQI}_{\mathrm{PM} 2.5}$ within unhealthy for sensitive groups (101-150) and unhealthy (151-200) range according to US EPA standards. Nevertheless, the AQI $\mathrm{I}_{\mathrm{PM} 2.5}$ level

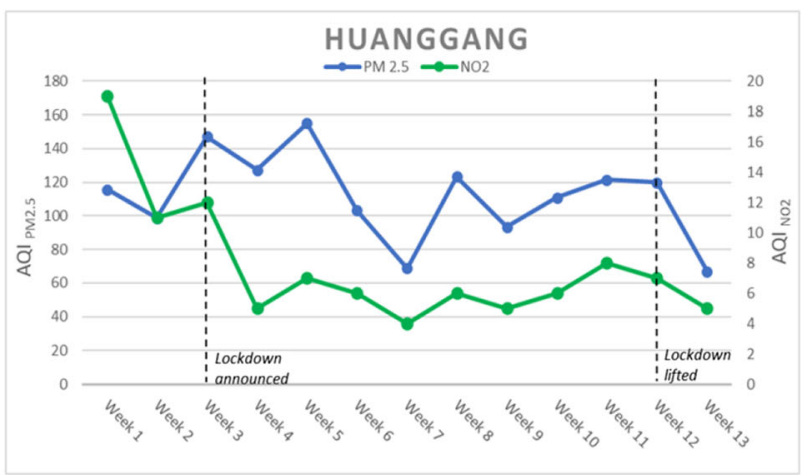

b

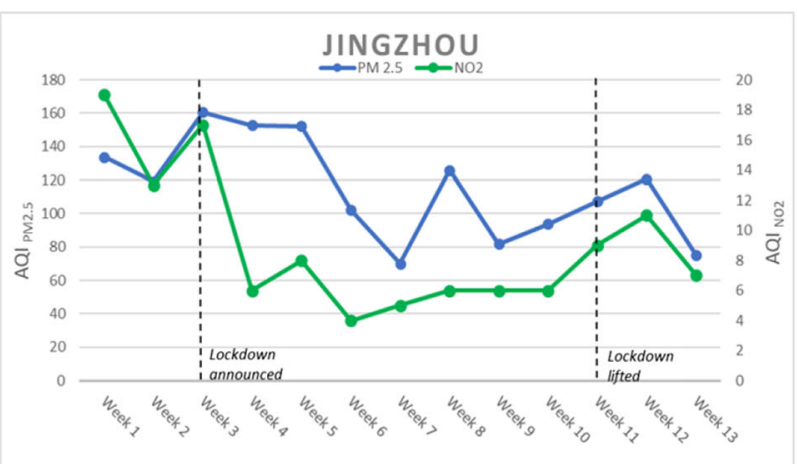

d

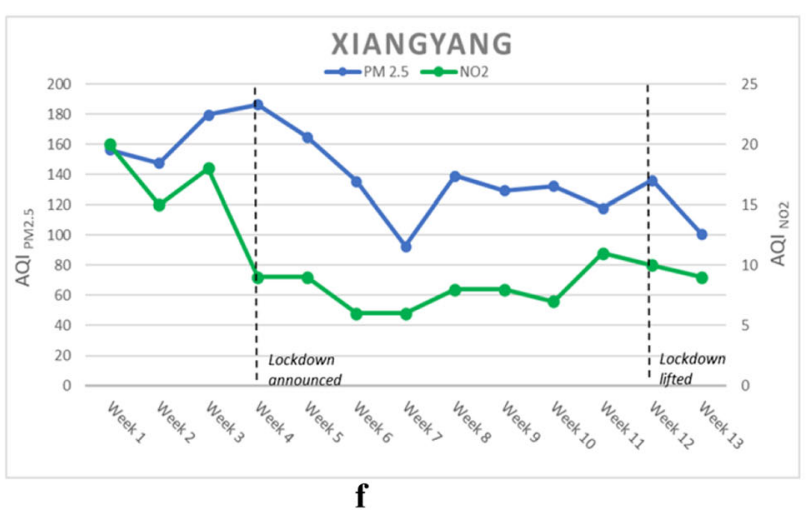


reduced and reached the moderate category during the lockdown period. Furthermore, for January, February, and March 2020, the cities recorded the lowest $\mathrm{AQI}_{\mathrm{PM} 2.5}$ levels in 5 years (Fig. 2a, b, c, d, e, and f). As the virus started to

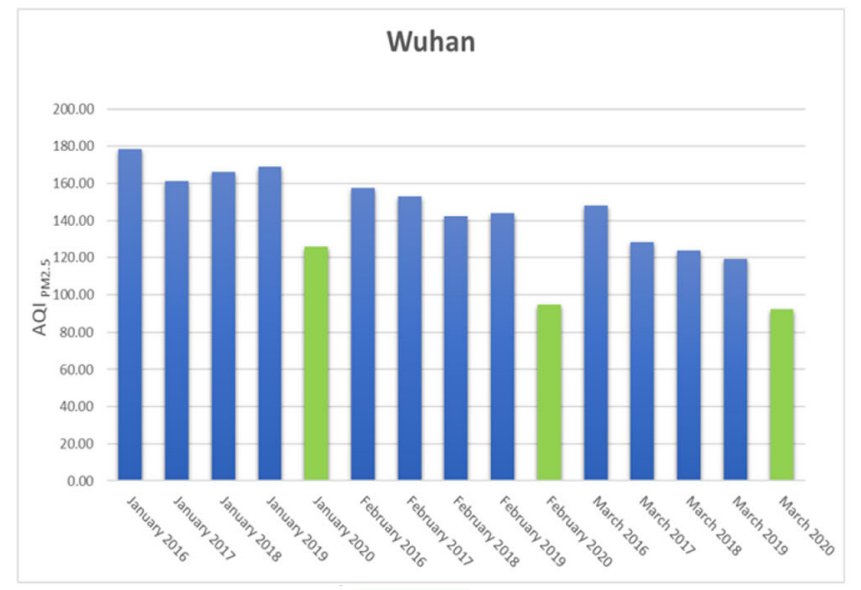

a

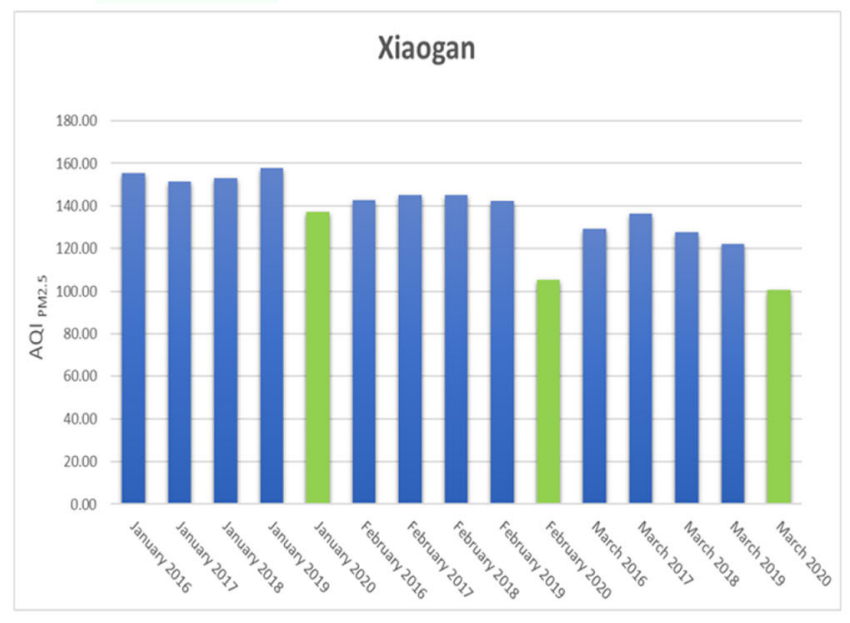

c

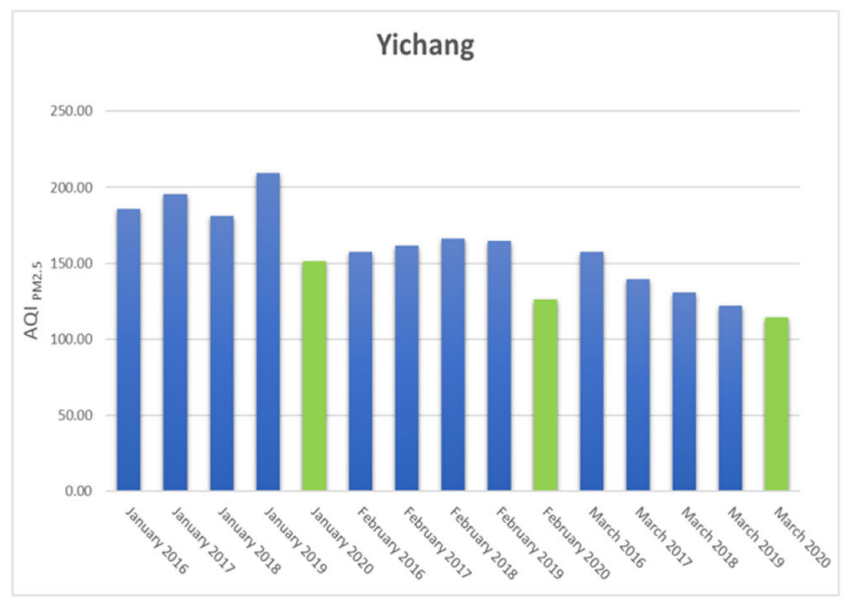

e

Fig. 2 Past 5 years' averages of $\mathrm{AQI}_{\mathrm{PM} 2.5}$ for cities of China spread in Hubei province in January, the citizens avoided leaving their homes as a self-precautionary measure. As the lockdown was implemented from January 23, 2020 in various cities, a drastic drop has been recorded in $\mathrm{AQI}_{\mathrm{PM} 2.5}$ levels

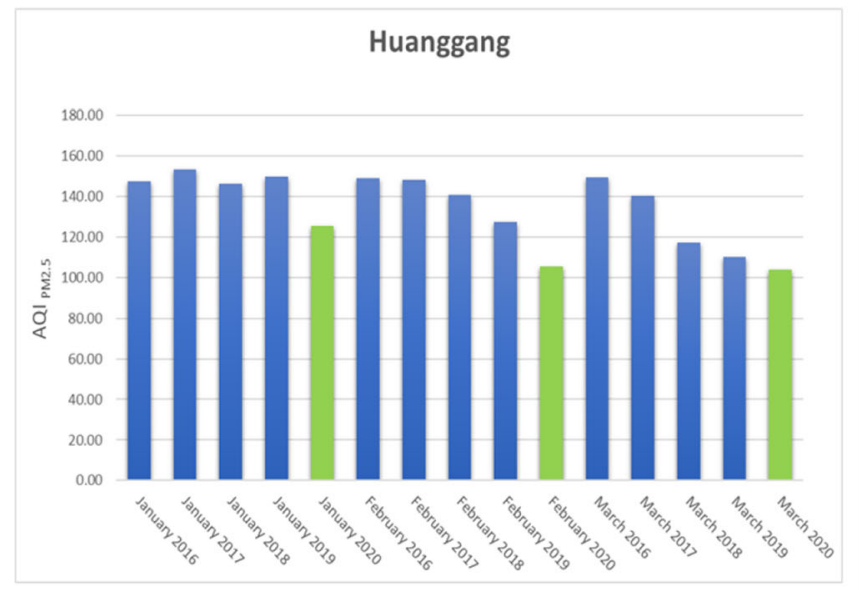

b

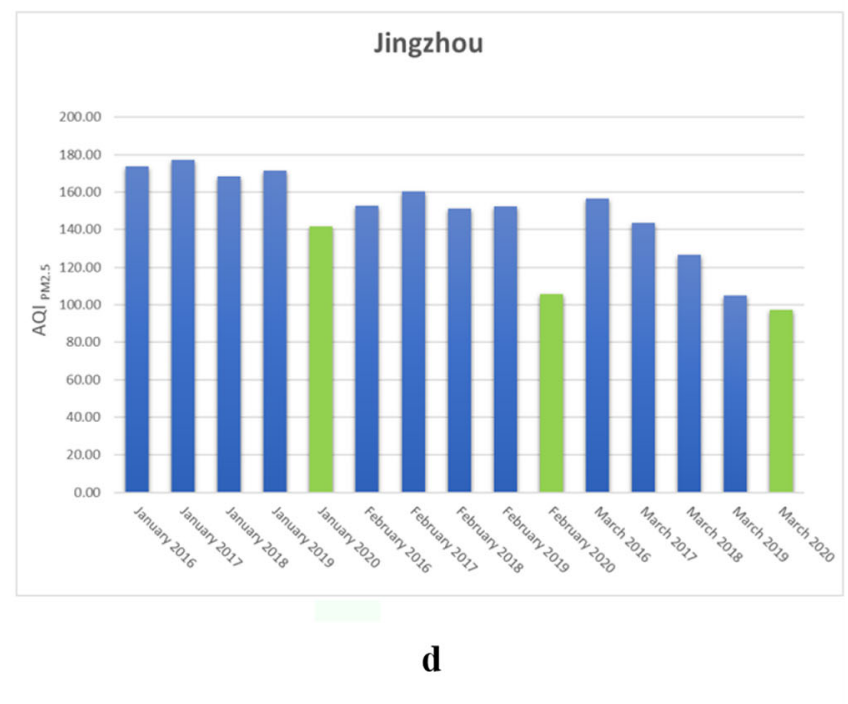

Xiangyang

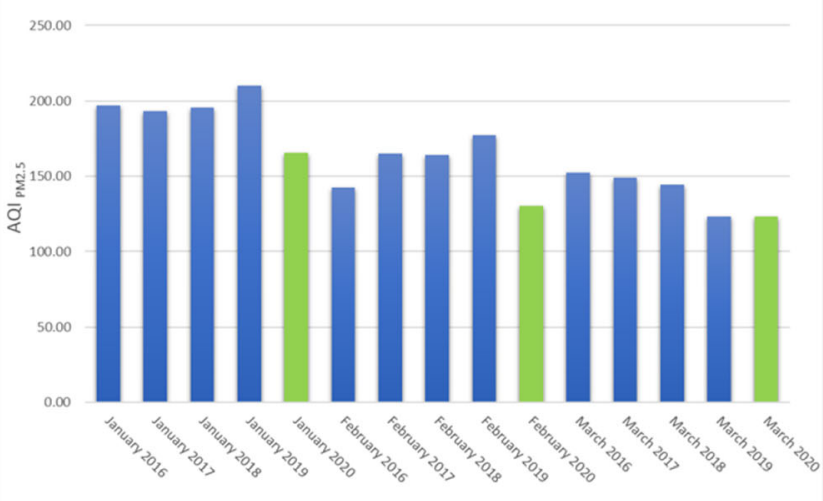

f 
from week 3 to week 4 (Fig. 1a, b, c, d, e, and f). The AQI $I_{P M 2.5}$ level remained constant through 2016-2019, to a certain degree for January and February. The highest 5-year and 1-year $\mathrm{AQI}_{\mathrm{PM} 2.5}$ drop were recorded in Wuhan: $39.96 \%$ and $34.21 \%$, respectively, while the lowest was found in Xiangyang: $8.53 \%$ and $26.55 \%$, respectively. The average 5-year $\mathrm{AQI}_{\mathrm{PM} 2.5}$ drop for January, February, and March, are $18.14 \%, 25.74 \%$, and 29.18\%, respectively. Subsequently, the average 1-year AQI $\mathrm{PM}_{\mathrm{PM} .5}$ drop for January, February, and March are $20.17 \%, 26.31 \%$, and $9.97 \%$, respectively. It can be recorded that the 5-year and 1-year $\mathrm{AQI}_{\mathrm{PM} 2.5}$ drop percentages are comparable in all months except March.

Additionally, meteorological conditions have an essential influence on the variations of $\mathrm{PM}_{2.5}$ and $\mathrm{NO}_{2}$ concentrations in the ambient environment (Agarwal et al. 2006). The cities Wuhan, Huanggang, and Xiaogan recorded a spike of $\mathrm{AQI}_{\mathrm{PM} 2.5}$ and $\mathrm{AQI}_{\mathrm{NO} 2}$ levels (Fig. 1a, b, and c) in week 5 which led to a gradual decline in the forthcoming weeks of $\mathrm{AQI}_{\mathrm{PM} 2.5}$ and $\mathrm{AQI}_{\mathrm{NO} 2}$. The increase in the AQI levels was due to low precipitation recorded in week 5 in the three cities; total average precipitation for the three cities for week 4 and 5 were $42.6 \mathrm{~mm}$ and $0.34 \mathrm{~mm}$, respectively. In the subsequent weeks, rainfall intensity increased, which led to the drop in $\mathrm{AQI}_{\mathrm{PM} 2.5}$ and $\mathrm{AQI}_{\mathrm{NO} 2}$ levels; the total average rainfall in weeks 6 and 7 for the three cities were $19.94 \mathrm{~mm}$ and $22.07 \mathrm{~mm}$. In week 8 , it has been observed from the Fig. 1a, $\mathrm{b}, \mathrm{c}, \mathrm{d}$, e, and $\mathrm{f}$ that there is an increase in $\mathrm{AQI}_{\mathrm{PM} 2.5}$ and $\mathrm{AQI}_{\mathrm{NO} 2}$ levels. Wuhan experienced $4.2 \mathrm{~mm}$ precipitation in Week 8 , as compared with $28.6 \mathrm{~mm}$ and $39.4 \mathrm{~mm}$ precipitation in Week 7 and Week 9, respectively. Hence, the abrupt increase in $\mathrm{PM}_{2.5}$ and $\mathrm{NO}_{2}$ in the cities is due to the low precipitation received in central China in Week 8 (19th-25th, February 2020). In the 13th week, a sharp decrease in $\mathrm{AQI}_{\mathrm{PM} 2.5}$ and $\mathrm{AQI}_{\mathrm{NO} 2}$ levels is recorded. The mean rainfall in six cities in the 12th week is $14.23 \mathrm{~mm}$. In contrast, the 13th week recorded heavy precipitation in all cities with mean average rainfall as $66.36 \mathrm{~mm}$.

\section{Air quality analysis for the selected cities of India}

India enforced a nationwide lockdown from March 24, 2020, to May 3, 2020, after successive extensions as a preventive measure against COVID-19 pandemic. As the lockdown was implemented from March 24, 2020, a drastic drop has been recorded in $\mathrm{AQI}_{\mathrm{PM} 2.5}$ levels of all selected cities from week 7 to week 8 (Fig. 3a, b, c, d, e, and f). Maharashtra, western peninsular state of India, has recorded the most cases of COVID-19 and deaths, 12,296 and 521, respectively (MoHFW 2020), and among the six megacities of India. Its capital, Mumbai, has shown the highest immediate drop of both $\mathrm{AQI}_{\mathrm{NO} 2}$ and $\mathrm{AQI} \mathrm{PM}_{\mathrm{PM} .5}$, i.e. $76.28 \%$ and $34.02 \%$, respectively. Kolkata recorded the highest final $\mathrm{AQI}_{\mathrm{PM} 2.5}$ drop (76.67\%), and Lucknow recorded the least immediate drop in $\mathrm{AQI}_{\mathrm{PM} 2.5}(6.47 \%)$ partly due to negligible precipitation in week 8. Chennai experienced the least immediate and final drops of $\mathrm{AQI}_{\mathrm{NO} 2}$, which are $32.14 \%$ and $20.95 \%$, respectively. It can be understood because of Chennai having an already low value of $\mathrm{AQI}_{\mathrm{NO} 2}$ (Fig. 3a) in week 7 and the weeks before the lockdown (Table 2).

The 6 cities experienced an average immediate $\mathrm{AQI}_{\mathrm{PM} 2.5}$ drop of $20.21 \%$, and an average final $\mathrm{AQI}_{\mathrm{PM} 2.5}$ drop of $37.42 \%$. Each one of the six Indian cities in the study recorded an immediate and final $\mathrm{AQI}_{\mathrm{NO} 2}$ drop with the average immediate $\mathrm{AQI}_{\mathrm{NO} 2}$ drop of $59.26 \%$ and an average final $\mathrm{AQI}_{\mathrm{NO} 2}$ drop of $65.80 \%$. It has shown an overall drop in both $\mathrm{AQI}_{\mathrm{PM} 2.5}$ and $\mathrm{AQI}_{\mathrm{NO} 2}$. The average 5-year $\mathrm{AQI}_{\mathrm{PM} 2.5}$ drop for the months of February, March, and April is recorded as $16.05 \%, 26.68 \%$, and $37.51 \%$, respectively; subsequently, average 1-year $\mathrm{AQI}_{\mathrm{PM} 2.5}$ drop for the months of February, March, and April is $3.48 \%, 17.98 \%$, and $27.06 \%$, respectively. Chennai recorded the highest 5-year drop and 1-year drop in AQI $\mathrm{PM}_{\mathrm{PM} .5}$ in April 2020 as $59.79 \%$ and $42.90 \%$, respectively. All cities, except Mumbai in April 2020 and Chennai in March 2020, recorded the lowest AQI ${ }_{\mathrm{PM} 2.5}$ levels in March and April 2020 as compared with the past 5 years. Mumbai is the only Indian city in the study to have shown a 1-year rise (1.09\%) in an average AQI $\mathrm{PM}_{2.5}$ in April 2020 (Fig. 4a, b, c, d, e, and f). A spike in AQI $\mathrm{PM}_{2.5}$ was recorded (Table 3 ) between weeks 9 and 10 in New Delhi. It is as a result of reported fireworks incidents recorded on April 5, 2020, the day-wise $\mathrm{AQI}_{\mathrm{PM} 2.5}$ levels of week 9 and 10 are given in Fig. 3b (The Indian Express 2020).

Furthermore, meteorological factors have an essential factor in the reduction and increase of $\mathrm{PM}_{2.5}$ and $\mathrm{NO}_{2}$ concentrations in the ambient environment. It can be recorded from Fig. 3c, in Kolkata, that $\mathrm{AQI} \mathrm{PM}_{\mathrm{PM} .5}$ and $\mathrm{AQI}_{\mathrm{NO} 2}$ have decreased augmented by heavy precipitation in the weeks 11,12 , and 13 with $29.20 \mathrm{~mm}, 80.90 \mathrm{~mm}$, and $60.20 \mathrm{~mm}$, respectively. However, in the preceding weeks 9 and 10, there was no precipitation. On the other hand, New Delhi, Lucknow, and Jaipur recorded an increase in $\mathrm{AQI}_{\mathrm{PM} 2.5}$ in week 11 due to high surface winds in northern India due to dust storms from western India according to the Ministry of Environment and System of Air Quality and Weather Forecasting and Research (SAFAR) (Fig. 3b, e, and f) (ANI News 2020).

\section{Comparative analysis and discussion between China vs India}

An entire month lockdown was implemented in February 2020 in Hubei province, China; likewise in India, the month of lockdown was April 2020. The 1-year drop for February in China comes out to be $26.31 \%$, whereas, for April in India, it is $26.06 \%$. Hence, it can be deduced from the results that an entire month lockdown in urban centres results in a drop of around $26 \%$ in $\mathrm{AQI}_{\mathrm{PM} 2.5}$ if compared with previous year 


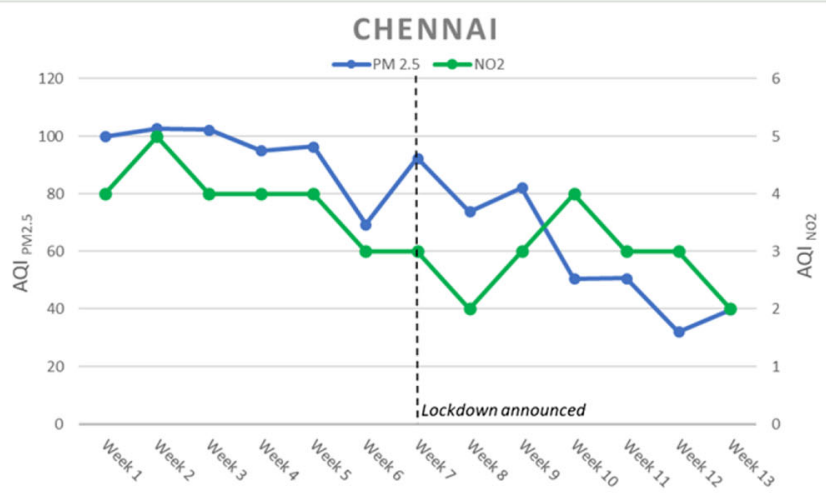

a

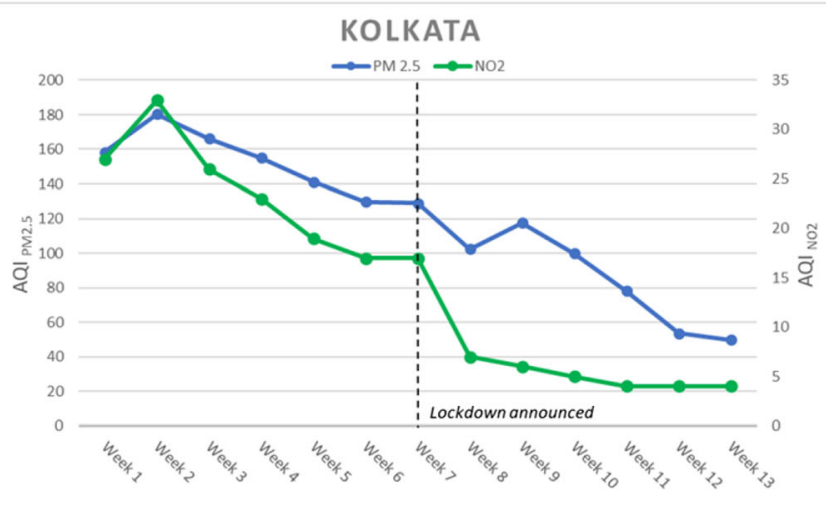

c

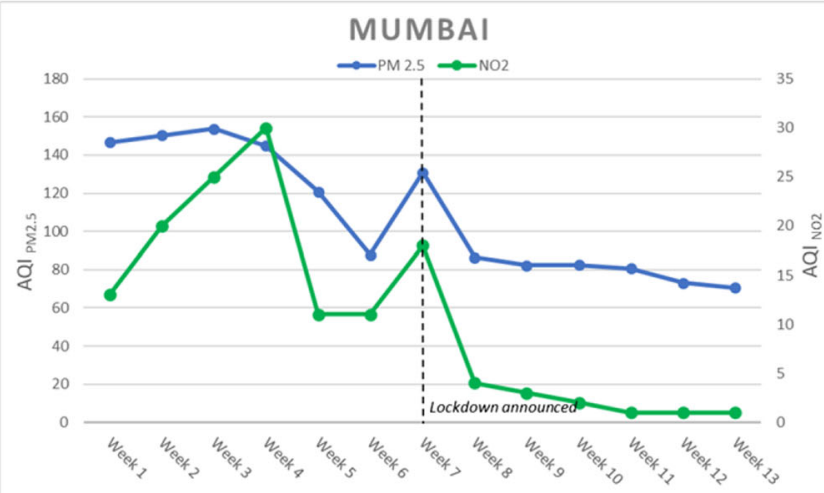

e

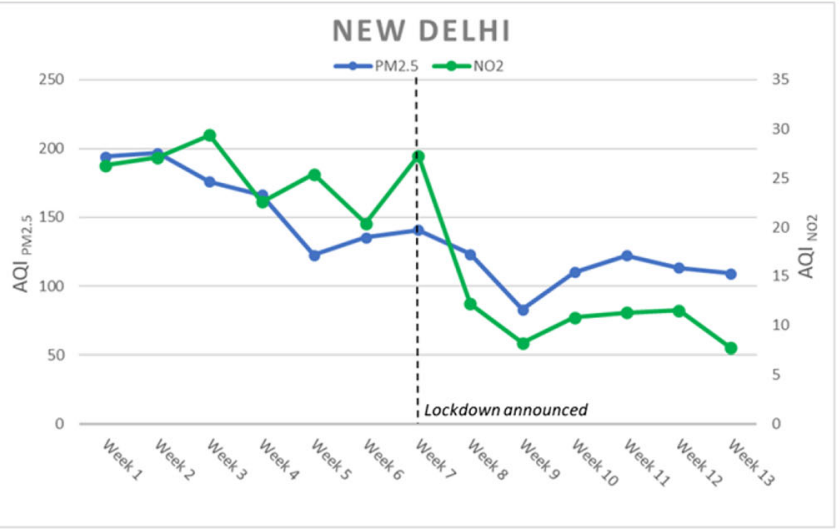

b

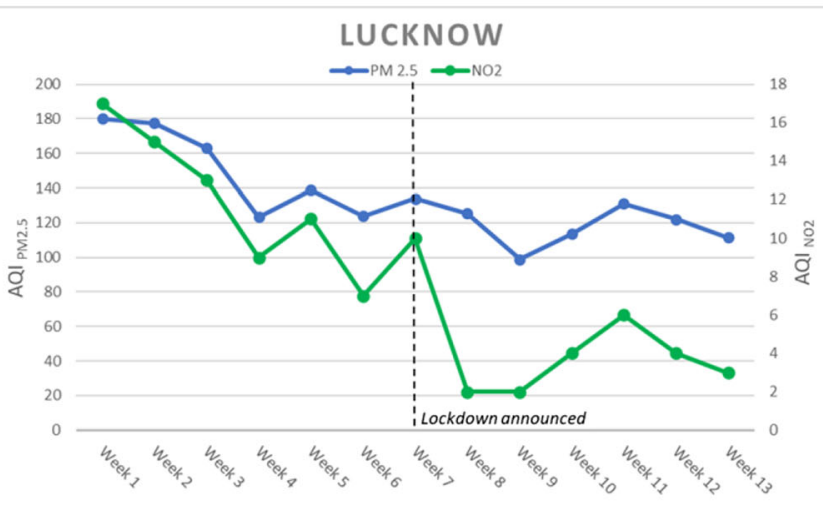

d

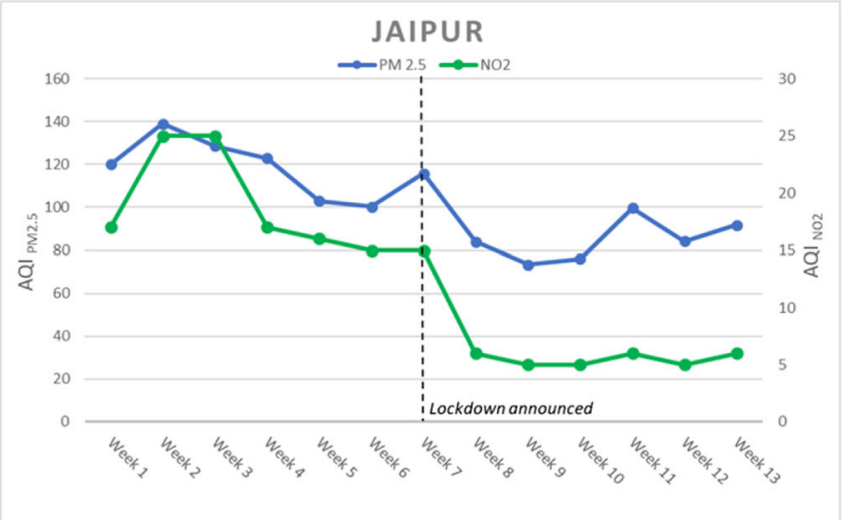

f

Fig. 3 Weekly averages of $\mathrm{AQI}_{\mathrm{PM} 2.5}$ and $\mathrm{AQI}_{\mathrm{NO} 2}$ for cities of India

Table 2 Chennai weekly AQI ${ }_{\mathrm{NO} 2}$ averages (CPCB-CCR 2020; Mintz 2012)

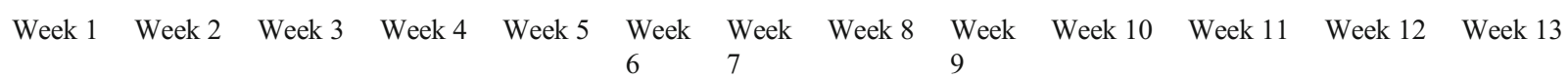

\begin{tabular}{llllllllllllllll}
\hline $\mathrm{AQI}_{\mathrm{NO} 2}$ & 4 & 5 & 4 & 4 & 4 & 3 & 3 & 2 & 3 & 4 & 3 & 3 & 2 \\
\hline
\end{tabular}




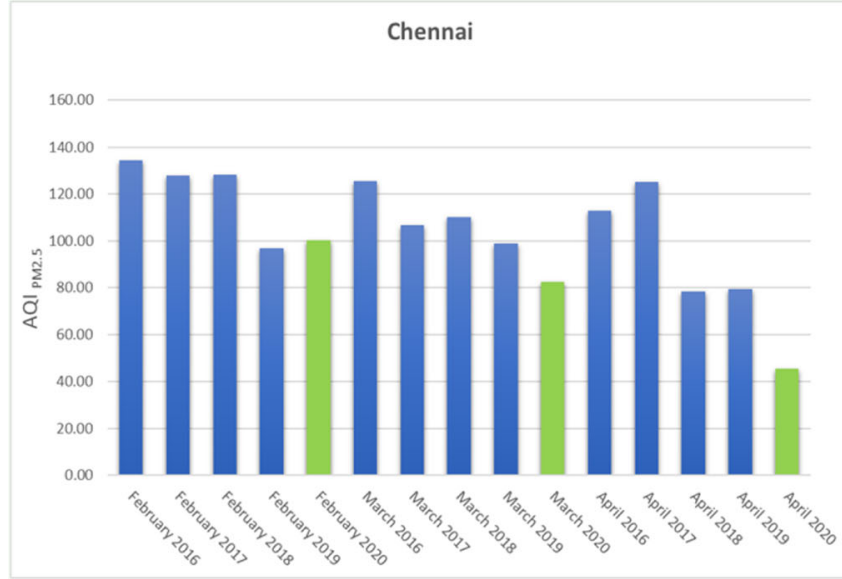

a

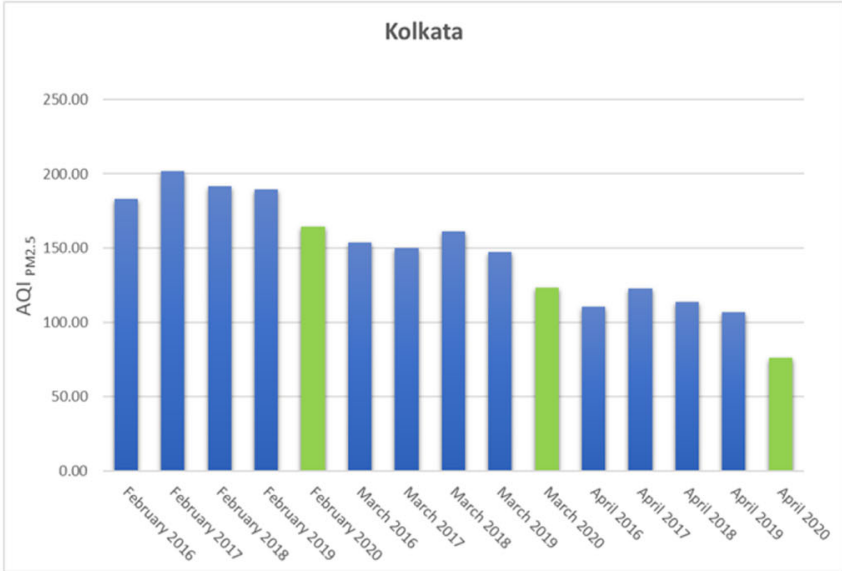

c

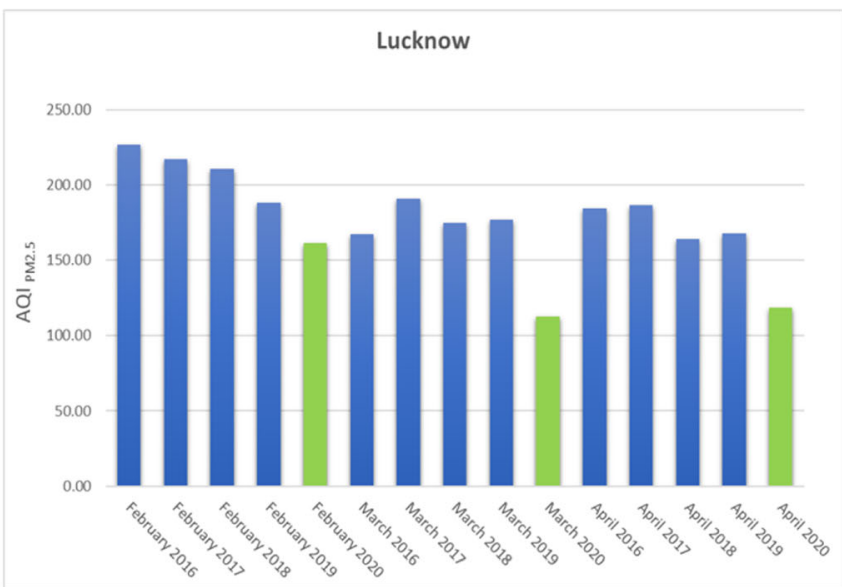

e

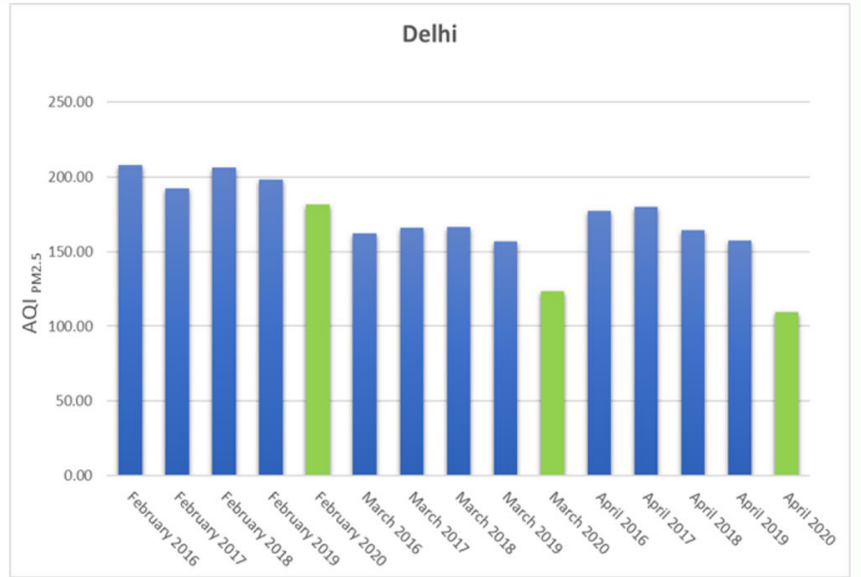

b

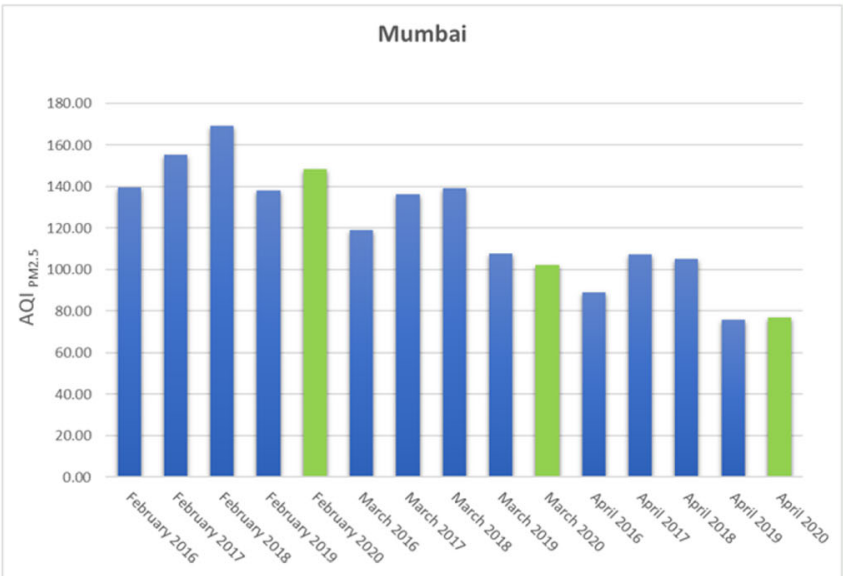

d

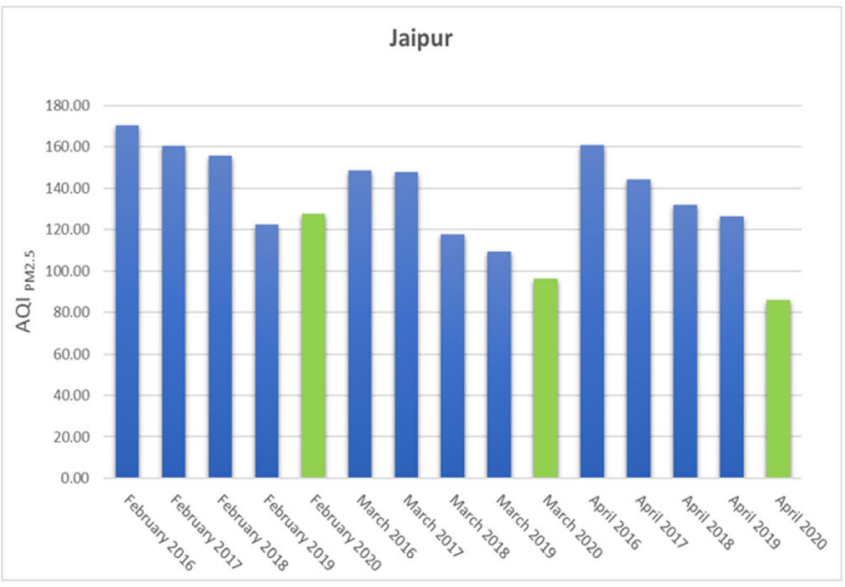

f

Fig. 4 Past 5 years' averages of $\mathrm{AQI}_{\mathrm{PM} 2.5}$ for cities of India

value. Several academic studies have been conducted to study the relationship between the local meteorological factors and concentration of various pollutants (viz. $\mathrm{PM}_{2.5}$ and $\left.\mathrm{NO}_{2}\right)(\mathrm{Guo}$ et al. 2017). The prime factors which influence the concentration of $\mathrm{PM}_{2.5}$ and $\mathrm{NO}_{2}$ have been identified as precipitation, ambient temperature, wind speed, and relative humidity. 
Table 3 Delhi daily $\mathrm{AQI}_{\mathrm{NO} 2}$ and $\mathrm{AQI}_{\mathrm{PM} 2.5}$ averages (CPCB-CCR 2020; Mintz 2012)

\begin{tabular}{|c|c|c|c|c|c|c|c|c|c|c|c|c|c|}
\hline & $\begin{array}{l}\text { April 1, } \\
2020\end{array}$ & $\begin{array}{l}\text { April 2, } \\
2020\end{array}$ & $\begin{array}{l}\text { April 3, } \\
2020\end{array}$ & $\begin{array}{l}\text { April 4, } \\
2020\end{array}$ & $\begin{array}{l}\text { April 5, } \\
2020\end{array}$ & $\begin{array}{l}\text { April 6, } \\
2020\end{array}$ & $\begin{array}{l}\text { April 7, } \\
2020\end{array}$ & $\begin{array}{l}\text { April 8, } \\
2020\end{array}$ & $\begin{array}{l}\text { April 9, } \\
2020\end{array}$ & $\begin{array}{l}\text { April 10, } \\
2020\end{array}$ & $\begin{array}{l}\text { April 11, } \\
2020\end{array}$ & $\begin{array}{l}\text { April 12, } \\
2020\end{array}$ & $\begin{array}{l}\text { April 13, } \\
2020\end{array}$ \\
\hline $\mathrm{AQI}_{\mathrm{NO} 2}$ & 7 & 9 & 10.75 & 12.33 & 11 & 8 & 9.5 & 11 & 13 & 11.67 & 8.33 & 12 & 12.33 \\
\hline $\mathrm{AQI}_{\mathrm{PM} 2.5}$ & 92.75 & 77.2 & 88.2 & 97.75 & 116 & 137 & 94.67 & 90.67 & 93.5 & 124.25 & 122.25 & 113 & 128.75 \\
\hline
\end{tabular}

However, the 12 selected cities tend to show a tremendous reduction in the concentration of $\mathrm{PM}_{2.5}$ and $\mathrm{NO}_{2}$ due to lockdown enforcement. It reflects that cutting down on anthropogenic sources of various pollutants can be useful in reducing the AQI.

Huanggang, China, has a population of 6.62 million, and the $\mathrm{AQI}_{\mathrm{PM} 2.5}$ and $\mathrm{AQI}_{\mathrm{NO} 2}$ of Huanggang before the lockdown were 147.1 and 12 , respectively. After the first week of implementation of lockdown, there was found a decrease of $13.40 \%$ and $58.54 \%$ in $\mathrm{AQI}_{\mathrm{PM} 2.5}$ and $\mathrm{AQI}_{\mathrm{NO} 2}$. Likewise, Jaipur, India, has a population of 6.42 million and the $\mathrm{AQI}_{\mathrm{PM} 2.5}$ and $\mathrm{AQI}_{\mathrm{NO} 2}$ of Jaipur before the lockdown was implemented were 115.7 and 15 , respectively. After the first week of the implementation of lockdown, a decrease of $27.50 \%$ and $60.37 \%$ in $\mathrm{AQI}_{\mathrm{PM} 2.5}$ and $\mathrm{AQI}_{\mathrm{NO} 2}$ was recorded. Both cities have a comparable population and immediate $\mathrm{AQI}_{\mathrm{NO} 2}$ drop, but the immediate $\mathrm{AQI}_{\mathrm{PM} 2.5}$ drop differs by $14.1 \%$. The lowest week average $\mathrm{AQI}_{\mathrm{PM} 2.5}$ recorded in Huanggang and Jaipur was recorded 68.7 and 73.4, respectively. Both the cities' AQI ${ }_{\mathrm{PM} 2.5}$ has dropped down from unhealthy for sensitive groups to moderate air quality. Within 4 weeks of implementation of lockdown, Huanggang experienced a drop of $53.30 \%$ and $65.85 \%$ in week average $\mathrm{AQI}_{\mathrm{PM} 2.5}$ and $\mathrm{AQI}_{\mathrm{NO} 2}$. Furthermore, Jaipur saw a drop of
$36.56 \%$ and $67.49 \%$ in week average $\mathrm{AQI}_{\mathrm{PM} 2.5}$ and $\mathrm{AQI}_{\mathrm{NO} 2}$ in just 2 weeks.

For a holistic view, the cities selected in India recorded an average immediate $\mathrm{AQI}_{\mathrm{PM} 2.5}$ and $\mathrm{AQI}_{\mathrm{NO} 2}$ drop of $20.21 \%$ and $59.26 \%$, respectively. In contrast, on the other hand, the cities in China recorded an average drop of $11.32 \%$ and $48.61 \%$, respectively. After 6 weeks of implementing the lockdown, cities in India recorded an average drop in $\mathrm{AQI}_{\mathrm{PM} 2.5}$ and $\mathrm{AQI}_{\mathrm{NO} 2}$ of $37.42 \%$ and $65.80 \%$, respectively, while cities in China recorded a drop of $42.54 \%$ and $56.67 \%$ respectively. From these results, it can be inferred that the drop in $\mathrm{PM}_{2.5}$ is rather gradual as compared with the sudden drop in $\mathrm{NO}_{2}$ concentrations throughout the cities.

As shown in Fig. 5, the drop in AQI $\mathrm{PM} 2.5_{\text {of }}$ of coastal cities (viz. Chennai, Mumbai, and Kolkata) is relatively more significant than inland cities. The exceptional drop in $\mathrm{AQI}_{\mathrm{PM} 2.5}$ in the coastal cities is vastly due to the coastal winds which are very prominent in these cities. Previous studies conducted in these coastal cities show that coastal regions show a significant drop in $\mathrm{PM}_{2.5}$ in the morning as compared with inland regions (Chen et al. 2020b; Gupta et al. 2004). The three coastal cities incorporated in the present study record an average immediate $\mathrm{AQI}_{\mathrm{PM} 2.5}$ drop of $24.96 \%$, and the final average $\mathrm{AQI}_{\mathrm{PM} 2.5}$ drop was found as $54.90 \%$. On the other hand,
Fig. 5 Immediate and final Drop percentages of $A \mathrm{AI}_{\mathrm{PM} 2.5}$ for all cities

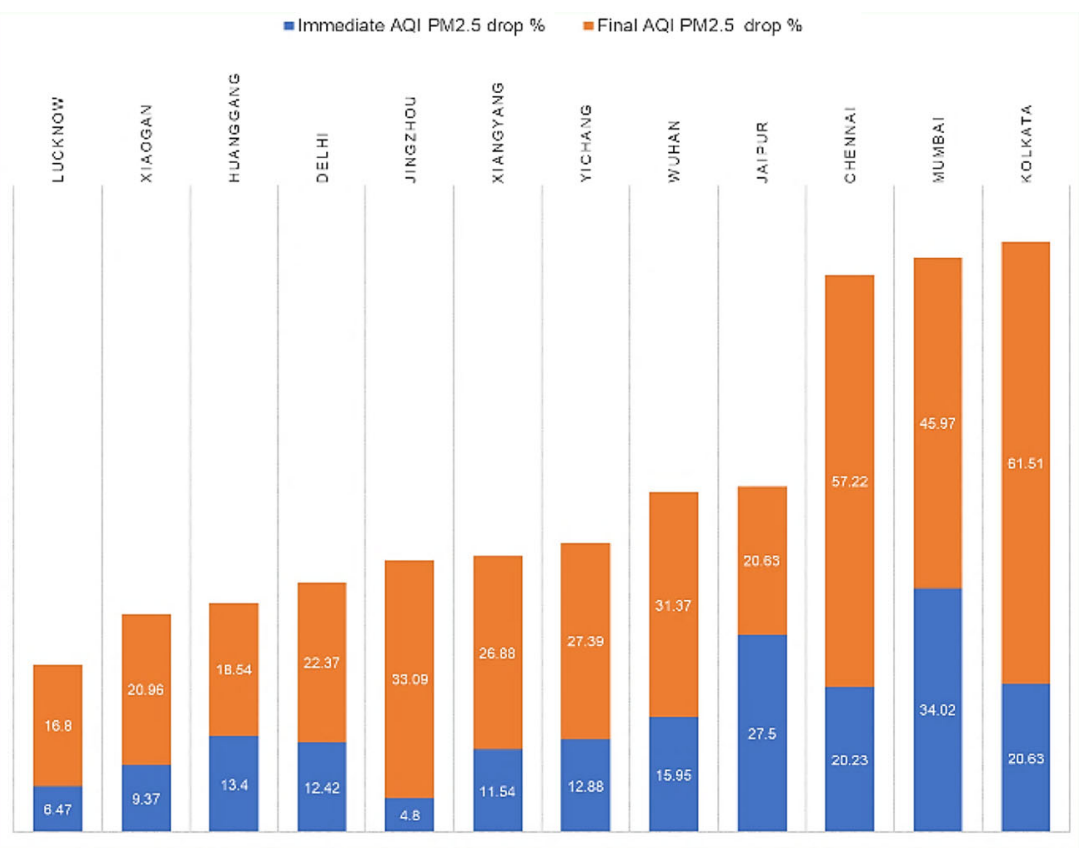


the inland region cities recorded an average immediate $\mathrm{AQI}_{\mathrm{PM} 2.5}$ drop of $12.70 \%$ and the final average $\mathrm{AQI}_{\mathrm{PM} 2.5}$ drop of $24.23 \%$. The drop in average immediate and final $\mathrm{AQI}_{\mathrm{PM} 2.5}$ of cities in inland regions is moderate as compared with the drop in coastal regions.

Drop-in $\mathrm{AQI}_{\mathrm{NO} 2}$ also shows similar trends as $\mathrm{AQI}_{\mathrm{PM} 2.5}$ (Fig. 6). The coastal cities recorded a much higher percentage of drop in $\mathrm{AQI}_{\mathrm{NO} 2}$ as compared with cities in inland regions. The coastal cities, except for Chennai, show an exceptionally high drop in $\mathrm{AQI}_{\mathrm{NO} 2}$. Mumbai and Kolkata recorded an immediate $\mathrm{AQI}_{\mathrm{NO} 2}$ drop of $76.28 \%$ and $55.70 \%$, respectively, whereas the final $\mathrm{AQI}_{\mathrm{NO} 2}$ drop is $92.58 \%$ and $76.67 \%$, respectively. However, Chennai is a coastal city that recorded a much lower percentage drop in $\mathrm{AQI}_{\mathrm{NO} 2}$ as compared with the other two coastal cities, $\mathrm{AQI}_{\mathrm{NO} 2}$ of Chennai was already at a record low values between 3 to 5 before even lockdown was implemented. Xiangyang recorded an increase in $\mathrm{AQI}_{\mathrm{NO} 2}$ levels after the implementation of lockdown. Xiangyang, being a heavily industrialised city, had industries that were operating during the lockdown to produce essential medical equipment.

\section{Conclusion}

Both the nations followed different protocols for implementing lockdown in each country, although the lockdown in both of the nations was found effective in declining the rate of spread of COVID-19 cases (Wang et al. 2020b; Barkur et al. 2020), and it played a significant role in reducing the air pollution to record low values. The significant findings of the study are as follows:
- In China, the week before the lockdown was enforced, 4

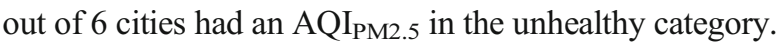
Wuhan and Huanggang were found in unhealthy for sensitive group category. In the last week of lockdown, 5 out of 6 cities were found to be in unhealthy for sensitive group category except for Wuhan, which was found in the moderate category.

- In India, the week before the lockdown was enforced, 5 out of 6 cities had an AQI $\mathrm{PM} 2.5_{\text {that }}$ is unhealthy for sensitive group category except Chennai that was found under the moderate category. In the sixth week of lockdown, all cities were found in the good and moderate category except Delhi and Lucknow, which were found to be in unhealthy for sensitive group category.

- Meteorological factors are an essential factor in order to address pollutant concentration in ambient environment. Henceforth, meteorological should be taken into account before the execution of a response plan to mitigate pollution in urban cities around the world.

- For all 12 cities, a gradual decline has been recorded in $\mathrm{AQI} \mathrm{I}_{\mathrm{PM} 2.5}$ levels in subsequent lockdown weeks. The mean immediate and final $\mathrm{AQI} \mathrm{I}_{\mathrm{PM} 2.5}$ drops are $15.76 \%$ and $31.89 \%$, respectively. However, in the case, $\mathrm{AQI}_{\mathrm{NO} 2}$ levels, a sharp decline has been recorded in the first week of lockdown. The mean immediate and final $\mathrm{AQI}_{\mathrm{NO} 2}$ drops are $53.93 \%$ and $46.22 \%$, respectively.

- The coastal cities (viz. Chennai, Mumbai, and Kolkata) recorded a more significant decline in $\mathrm{AQI}_{\mathrm{PM} 2.5}$ and $\mathrm{AQI}_{\mathrm{NO} 2}$ as compared with the other inland region cities.

The lockdown implemented in various regions around the world provided us with a unique opportunity to identify the
Fig. 6 Immediate and final Drop percentages of $\mathrm{AQI} \mathrm{I}_{\mathrm{NO} 2}$ for all cities

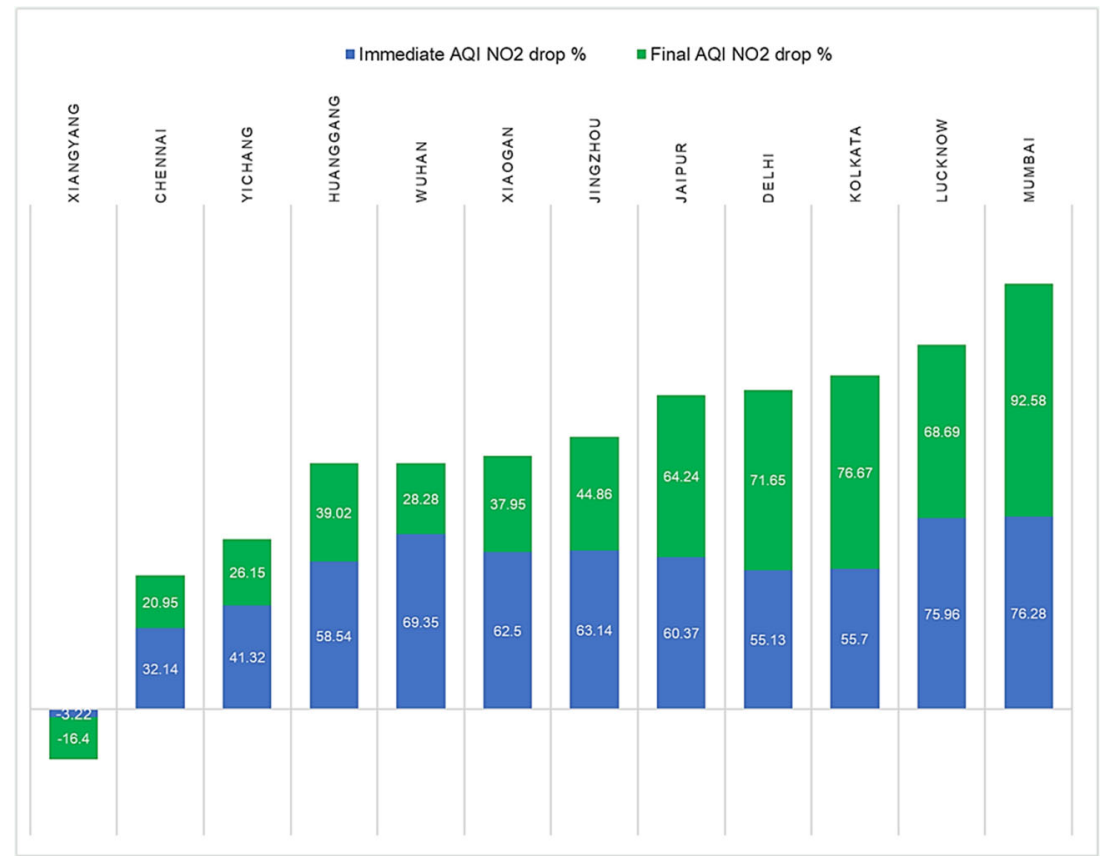


benchmark levels of pollutants in various urban cities around the world. The findings of the study will assist the governing authorities and policymakers to calibrate a proper response plan to bring down the ever-increasing pollution levels in various developing urban regions across the globe, especially China and India.

Acknowledgements Authors are incredibly grateful to Advance Air \& Acoustics Research Laboratory, Delhi Technological University, Delhi (India), for encouraging to conduct this research and providing all the facility to compile this work.

Funding information This research did not receive any specific grant from funding agencies in the public, commercial, or not-for-profit sectors.

Availability of data and material The data used in the current study have been taken from respective EPA and is available in public domain.

\section{Compliance with ethical standards}

Competing interests The authors declare that they have no known competing financial interest or personal relationships that would have appeared to influence the work reported in this paper.

\section{References}

Agarwal R, Jayaraman G, Anand S, Marimuthu P (2006) Assessing respiratory morbidity through pollution status and meteorological conditions for Delhi. Environ Monit Assess 114:489-504. https://doi. org/10.1007/s10661-006-4935-3

ANI News (2020) Delhi's air quality may deteriorate due to western dust storms: SAFAR. https://www.aninews.in/news/environment/delhisair-quality-may-deteriorate-due-to-western-dust-stormssafar20200415085141/. Accessed 1 Apr 2020

Barkur G, Vibha, Kamath GB (2020) Sentiment analysis of nationwide lockdown due to COVID 19 outbreak: evidence from India. Asian J Psychiatr 51:102089. https://doi.org/10.1016/j.ajp.2020.102089

Błaszczyk E, Rogula-Kozłowska W, Klejnowski K, Kubiesa P, Fulara I, Mielżyńska-Švach D (2017) Indoor air quality in urban and rural kindergartens: short-term studies in Silesia, Poland. Air Qual Atmos Health 10:1207-1220. https://doi.org/10.1007/s11869-017-0505-9

Central Intelligence Agency (2018) The World Factbook. https://www. cia.gov/library/publications/the-world-factbook/fields/344rank. html. Accessed 18 Apr 2020

Chen N, Zhou M, Dong X, Qu J, Gong F, Han Y, Qiu Y, Wang J, Liu Y, Wei Y, Xia J, Yu T, Zhang X, Zhang L (2020a) Epidemiological and clinical characteristics of 99 cases of 2019 novel coronavirus pneumonia in Wuhan, China: a descriptive study. Lancet 395:507513. https://doi.org/10.1016/s0140-6736(20)30211-7

Chen Y, Wild O, Conibear L, Ran L, He J, Wang L, Wang Y (2020b) Local characteristics of and exposure to fine particulate matter (PM2.5) in four Indian megacities. Atmos Environ X 5:100052. https://doi.org/10.1016/j.aeaoa.2019.100052

Conticini E, Frediani B, Caro D (2020) Can atmospheric pollution be considered a co-factor in extremely high level of SARS-CoV-2 lethality in northern Italy? Environ Pollut 261:114465. https://doi.org/ 10.1016/j.envpol.2020.114465

CPCB-CCR (2020) Central control room for air quality management - all India. https://app.cpcbccr.com/ccr/\#/caaqm-dashboard-all/caaqmlanding/data. Accessed 16 Apr 2020
Fan H, Zhao C, Yang Y (2020) A comprehensive analysis of the spatiotemporal variation of urban air pollution in China during 2014 2018. Atmos Environ 220:117066. https://doi.org/10.1016/j. atmosenv.2019.117066

Guo J, Xia F, Zhang Y, Liu H, Li J, Lou M, He J, Yan Y, Wang F, Min M, Zhai P (2017) Impact of diurnal variability and meteorological factors on the PM2.5 - AOD relationship: implications for PM2.5 remote sensing. Environ Pollut 221:94-104. https://doi.org/10.1016/j. envpol.2016.11.043

Gupta A, Patil RS, Gupta S (2004) Influence of meteorological factors on air pollution concentration for a coastal region in India. Int J Environ Pollut 21:253. https://doi.org/10.1504/ijep.2004.004193

Health Effects Institute (2019) State of Global Air 2019. Special Report. Health Effects Institute, Boston

Hubei Provincial People's Government (2020) Hubei Enterprises. http:// en.hubei.gov.cn/business/enterprises/. Accessed 3 Apr 2020

IEA OECD (2016) Energy and Air Pollution: World Energy Outlook Special Report 2016

Jain S, Sharma T (2020) Social and travel lockdown impact considering coronavirus disease (COVID-19) on air quality in megacities of India: present benefits, future challenges and way forward. Aerosol Air Qual Res 20:1222-1236. https://doi.org/10.4209/aaqr. 2020.04.0171

Kumar R, Joseph AE (2006) Air pollution concentrations of PM2.5, $\mathrm{PM} 10$ and NO2 at ambient and Kerbsite and their correlation in Metro City - Mumbai. Environ Monit Assess 119:191-199. https://doi.org/10.1007/s10661-005-9022-7

Kumar A, Mishra RK (2018) Human health risk assessment of major air pollutants at transport corridors of Delhi, India. J Transp Health 10: 132-143. https://doi.org/10.1016/j.jth.2018.05.013

Li S, Feng K, Li M (2017) Identifying the main contributors of air pollution in Beijing. J Clean Prod 163:S359-S365. https://doi.org/10. 1016/j.jclepro.2015.10.127

Liu H, Tian Y, Song J, Cao Y, Xiang X, Huang C, Li M, Hu Y (2018) Effect of ambient air pollution on hospitalization for heart failure in 26 of Chinas largest cities. Am J Cardiol 121:628-633. https://doi. org/10.1016/j.amjcard.2017.11.039

Lu D (2020) Inside Wuhan's lockdown. New Sci 245:7. https://doi.org/ $10.1016 / \mathrm{s} 0262-4079(20) 30234-7$

Ministry for the Environment New Zealand (2020) Nitrogen dioxide. https://www.mfe.govt.nz/air/specific-air-pollutants/nitrogendioxide. Accessed 5 Apr 2020

Mintz D (2012) Technical assistance document for the reporting of daily air quality - the air quality index. EPA-454/B-12-001

MoHFW, Ministry of Health and Family Welfare (2020) COVID-19 INDIA. https://www.mohfw.gov.in/. Accessed 2 Apr 2020

National Bureau of Statistics of China (2010) Census Data http://www. stats.gov.cn/english/Statisticaldata/CensusData/. Accessed 5 May 2020

National Health Commission of the People's Republic of China (2020) April 30: Daily briefing on novel coronavirus cases in China. http:// en.nhc.gov.cn/2020-05/16/c_80207.htm. Accessed 30 Apr 2020

Office of the Registrar General \& Census Commissioner, India (2011) 2011 Census Data. http://censusindia.gov.in/2011-Common/ CensusData2011.html. Accessed 22 Apr 2020

Pant P, Harrison RM (2012) Critical review of receptor modelling for particulate matter: a case study of India. Atmos Environ 49:1-12. https://doi.org/10.1016/j.atmosenv.2011.11.060

Park S, Allen RJ, Lim CH (2020) A likely increase in fine particulate matter and premature mortality under future climate change. Air Qual Atmos Health 13:143-151. https://doi.org/10.1007/s11869019-00785-7

Rodríguez MC, Dupont-Courtade L, Oueslati W (2016) Air pollution and urban structure linkages: evidence from European cities. Renew Sust Energ Rev 53:1-9. https://doi.org/10.1016/j.rser.2015.07.190 
Siddique S, Ray MR, Lahiri T (2010) Effects of air pollution on the respiratory health of children: a study in the capital city of India. Air Qual Atmos Health 4:95-102. https://doi.org/10.1007/s11869010-0079-2

The Indian Express (2020) Indian outrage on social media after people light fireworks, lead processions after lights off. https:// indianexpress.com/article/trending/trending-in-india/primisniternarendra-modi-9pm9minutes-coronavirus-6349647/. Accessed 5 May 2020

UN Environment Programme (2018) Air pollution: know your enemy. https://www.unenvironment.org/news-and-stories/story/airpollution-know-your-enemy. Accessed 2 Apr 2020

US EPA (2018) Particulate Matter (PM) Basics. https://www.epa.gov/ pm-pollution/particulate-matter-pm-basics. Accessed 12 Mar 2020

Venkatram A, Schulte N (2018) Urban transportation and air pollution. Elsevier Science Publishing Co Inc, s.l.

Wang P, Chen K, Zhu S, Wang P, Zhang H (2020a) Severe air pollution events not avoided by reduced anthropogenic activities during COVID-19 outbreak. Resour Conserv Recycl 158:104814. https:// doi.org/10.1016/j.resconrec.2020.104814

Wang S-X, Wang Y, Lu Y-B, Li J-Y, Song Y-J, Nyamgerelt M, Wang X$X$ (2020b) Diagnosis and treatment of novel coronavirus pneumonia based on the theory of traditional Chinese medicine. Journal of Integrative Medicine 18:275-283. https://doi.org/10.1016/j.joim. 2020.04.001

WHO (2020) Coronavirus Disease (COVID-19) Situation Reports. https://www.who.int/emergencies/diseases/novel-coronavirus2019/situation-reports. Accessed 30 Apr 2020
Wilder-Smith A, Freedman DO (2020) Isolation, quarantine, social distancing and community containment: pivotal role for old-style public health measures in the novel coronavirus (2019-nCoV) outbreak. J Travel Med 27. https://doi.org/10.1093/jtm/taaa020

World Health Organization (2005) WHO Air quality guidelines for particulate matter, ozone, nitrogen dioxide and sulphur dioxide: global update 2005: summary of risk assessment (No. WHO/SDE/PHE/ $\mathrm{OEH} / 06.02)$

Wu JT, Leung K, Leung GM (2020a) Nowcasting and forecasting the potential domestic and international spread of the 2019-nCoV outbreak originating in Wuhan, China: a modelling study. Lancet 395: 689-697. https://doi.org/10.1016/s0140-6736(20)30260-9

Wu X, Nethery RC, Sabath BM, Braun D, Dominici F (2020b) Exposure to air pollution and COVID-19 mortality in the United States: a nationwide cross-sectional study. https://doi.org/10.1101/2020.04. 05.20054502

Zhang L, Wang B, Zhou J, Kirkpatrick J, Xie M, Johri AM (2020) Bedside focused cardiac ultrasound in COVID-19 infection from the Wuhan epicenter: the role of cardiac point of care ultrasound (POCUS), Limited Transthoracic Echocardiography and Critical Care Echocardiography. J Am Soc Echocardiogr 33:676-682. https://doi.org/10.1016/j.echo.2020.04.004

Zhu Z (2005) Political economy of China and India: dealing with air pollution in the two booming economies. Historia Actual Online 7:123-132

Publisher's note Springer Nature remains neutral with regard to jurisdictional claims in published maps and institutional affiliations. 